\title{
Одночастотный волоконный лазер с коротким резонатором, изготовленный на основе фоточувствительного Er/Yb фосфоросиликатного световода
}

\author{
А.А. Рыбалтовский ${ }^{1}$, Д.С. Липатов ${ }^{2}$, М.Е. Белкин ${ }^{3}, \underline{\text { O.В. Бутов }}^{1}$ \\ ${ }^{1}$ Институт Радиотехники и Электроники им. В.А. Котельникова РАН \\ ${ }^{2}$ Институт химии высокочистых веществ им. Г.Г. Девятых РАН \\ ${ }^{3}$ МИРЭА - Российский технологический университет \\ *E-mail: obutov@mail.ru
}

DOI: 10.31868/RFL2020.65-66

Одночастотные волоконные лазеры представляют большой интерес для применения в телекоммуникационном диапазоне длин волн (1500-1600 нм) в качестве компактных, малошумящих и помехоустойчивых источников эталонного сигнала. Длина резонатора одночастотных волоконных лазеров составляет обычно несколько сантиметров, а в качестве основы для их изготовления чаще всего применяются высоколегированные эрбиевые световоды. Однако из-за высокой вероятности ап-конверсионных процессов в таких лазерах нередко возникает самопроизвольный импульсный режим генерации, являющийся существенным ограничением для их практического использования [1]. Таким образом, решение проблемы создания непрерывных одночастотных лазеров во многом зависит от успехов в области разработки активных световодов с оптимальным составом стекла сердцевины.

Заготовка (преформа) экспериментального световода была изготовлена методом модифицированного химического осаждения из газовой фазы (MCVD), с осаждением всех составляющих стекло компонентов из газовой фазы. В качестве прекурсоров использовались легкокипящие $\mathrm{SiCl}_{4}, \mathrm{POCl}_{3}, \mathrm{CCl}_{4}, \mathrm{C}_{2} \mathrm{~F}_{3} \mathrm{Cl}_{3}$, а также мало-летучие хелаты - $\operatorname{Er}(\text { thd })_{3}$ и $\mathrm{Yb}(\mathrm{thd})_{3}$. Изготовление стекла сердцевины путем последовательного осаждения тонких слоев фосфоросиликатной матрицы, каждый из которых дополнительно пропитывался оксидами эрбия и иттербия, обеспечило итоговую высокую концентрацию активных ионов. При концентрации оксида фосфора 11 мол. \% значения концентраций оксидов эрбия и иттербия в сердцевине заготовки составили 0.1 и 0.8 мол. \% соответственно.

Из заготовки был вытянут одномодовый световод с внешним диаметром кварцевой оболочки 125 мкм, длиной волны отсечки высшей моды сердцевины 950 нм и разностью показателей преломления сердцевины и оболочки 0.014. Интенсивность поглощения на длине волны 976 нм в световоде составила 1500 дБ/м, а интенсивность поглощения ионов эрбия в пике на длине волны 1535 нм - 60 дБ/м. Уровень «серых» оптических потерь в световоде не превышал 0.04 дБ/м.

Резонатор волоконного лазера типа Фабри-Перо был сформирован целиком на отрезке активного световода общей длиной $~ 3$ см. На расстоянии $\sim 9$ мм друг от друга были записаны две волоконные брэгговские решётки показателя преломления длиной 10 мм каждая с коэффициентами отражения 99.9 и $94.3 \%$, выполняющие функцию «глухого» и выходного зеркал резонатора соответственно. Запись решёток осуществлялась с помощью прошедшего через фазовую маску с периодом 1072 нм фокусированного лазерного импульсного УФ-излучения с плотностью энергии в импульсе 150 мДж/см². В качестве 
источника такого излучения использовался эксимерный $\operatorname{ArF}$ лазер Coherent COMPexPro, генерирующий на длине волны 193 нм импульсы длительностью 20 нс с частотой повторения 10 Гц. Для повышения фоточувствительности к УФоблучению образец активного световода предварительно выдерживался в атмосфере молекулярного водорода при температуре 373К и давлении 12 МПа в течение 24 часов до полного насыщения сердцевины водородом.

Для накачки лазерного резонатора использовалась волоконная схема, описанная в [1]. Излучение накачки вводилось через волоконный фильтрмультиплексор 976/1550 навстречу распространению излучения волоконного лазера. Источником ИК-излучения с длиной волны 976 нм в настоящей работе являлся лазерный диод Gooch \& Housego D500-0976-SM с максимальной выходной мощностью 600 мВт. Пороговое значение мощности накачки, при котором возникала лазерная генерация, составило 100 мВт. Регистрация оптического спектра излучения лазера проводилась с высоким спектральным разрешением 0,016 нм при помощи оптического анализатора спектра Yokogawa AQ6370D. Спектр излучения лазера, измеренный вблизи порога генерации, приведён на рис. 1(a). В отличие от лазеров, являвшихся предметом исследований предыдущих работ [1] и [2], данный лазер генерировал непрерывное излучение начиная с пороговых значений мощности накачки и при комнатной температуре (295 К). В течение 2 часов был зафиксирован строго непрерывный характер излучения лазера на длине волны 1551,6 нм, при отсутствии признаков паразитной генерации ионов иттербия в диапазоне длин волн 1000-1100 нм.
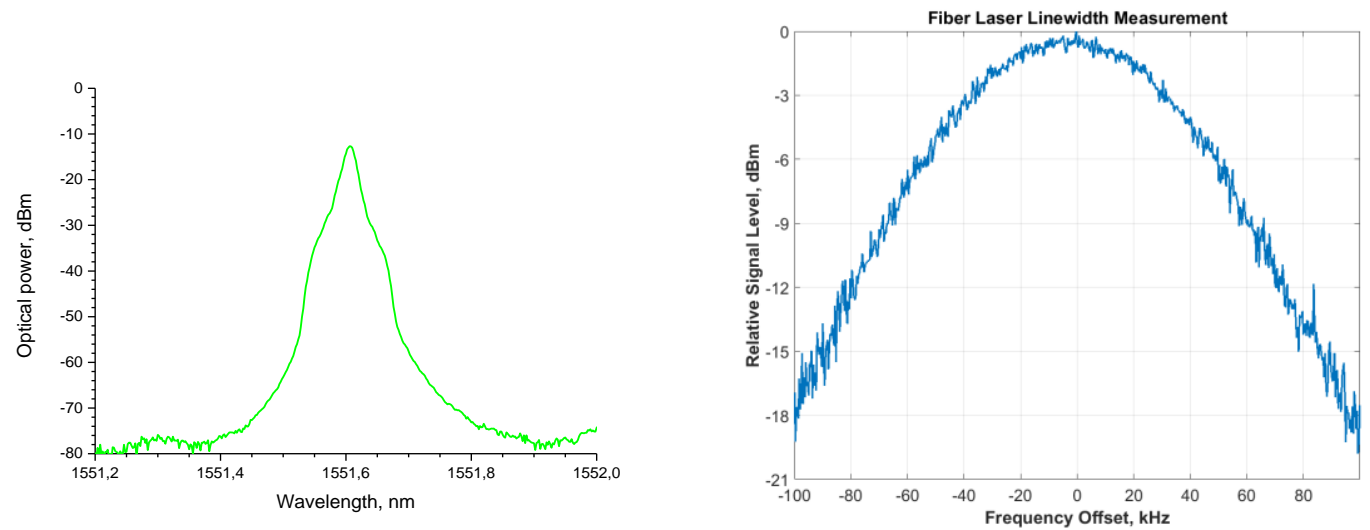

Рис. 1. Спектральные характеристики лазера, изготовленного на отрезке $\mathrm{Er} / \mathrm{Yb}$ фосфоросиликатного световода: оптический спектр излучения лазера (a); результат измерения ширины спектральной линии (б).

Измерения ширины спектральной линии лазера были проведены с помощью гетеродинной схемы и методики, описанной в работе [3]. Основными элементами экспериментальной установки для измерения ширины линии в настоящей работе являлись: акустооптический модулятор Brimrose AMF-100-1550-2FP+, радиочастотный генератор Keysight N5181B и анализатор спектра Agilent E4448A. В качестве линии задержки использовалась катушка со стандартным телекоммуникационным световодом длиной 25 км. Результаты измерения РЧспектра сигнала с фотодетектора представлены на рис. 1(б). Собственная ширина спектральной линии, определённая с помощью аппроксимации данного спектра функцией Фойгта, составила 35 кГц. 


\section{Литература}

[1] A. M. Smirnov, A. P. Bazakutsa et al. ACS Photonics 5, 5038-5046 (2018)

[2] A.A. Rybaltovsky, O.V. Butov et al. Results in Physics 16, 102832 (2020)

[3] M.Е. Белкин, Л.И. Жуков: Фотоника и радиофотоника в радиоэлектронных системах сверхвысокочастотного диапазона: учебно-методическое пособие, Московский технологический университет (МИРЭА), 2017. -64 с 